\title{
Recent Trends in Happiness Research
}

\author{
Aprajita Narula, Mani Bhasin Kalra
}

\begin{abstract}
Happiness is a subjective term conceptualized in varied ways by individuals and across disciplines. However, how it comes to be understood in reference to the educational context can provide directions for future endeavors in increasing student happiness, or well-being, the terms often used interchangeably. The term well-being, nonetheless, has gained more prominence owing to a broader spectrum of features it encompasses. The discipline of positive psychology which has received eminent advancement in recent times has offered a plethora of approaches to improve well-being of individuals. The VIA classification of strengths by Christopher Peterson and Martin Seligman (2004), offers a framework of 24 positive traits condensed further into 6 virtues, emphasizing employment of simple strategies to foster inherent strengths possessed by individuals in varying degrees, for accomplishing a greater sense of well-being. This review paper, examines the empirical evidence of the influence of various strengths and virtues as delineated in the VIA classification of strengths and other positive psychology interventions on well-being. The impact of various intervention studies with school and university students is also looked at. Evidence has revealed correlation between positive psychology interventions on strengthening character strengths and student well-being across cultures. Simple intervention strategies, such as practicing gratitude, mindfulness and social skills enhancement exercises led to decrease in negative affect and increased levels of positive affect and life satisfaction. Further, as it may be aptly believed that for any school-based intervention to reap benefits in a sustainable manner, the role of teachers cannot be undermined. The paper attempts to highlight the role of teachers in advancement of student well-being, their conceptualization, attitudes and their own sense of well-being which has a bearing on their classroom management styles as evidenced in research.
\end{abstract}

Keywords: Happiness, education, well-being, positive psychology, well-being interventions.

\section{INTRODUCTION}

Grim is the possibility of imagining a person who would look for unhappiness, abundance however the availability of people experiencing it is. Why it that a sentiment not sought for is is becoming all pervasive? Although our ancient texts and spiritual gurus have for long pointed the causes of unhappiness, wealth of research across the fields of psychology, philosophy, economics, education and sociology has also contributed in indicating various stressors of life that cause disequilibrium of mental states and experiences of distress and unhappiness. Economic hardships, low quality marriages, disease, loss of loved ones, unemployment, social

Revised Manuscript Received on July 22, 2019.

Aprajita Narula, Research Scholar, Department of Human Development and Childhood Studies, University of Delhi, New Delhi, India.

Dr.Mani Bhasin Kalra, Associate Professor, Department of Education, Lady Irwin College, University of Delhi, New Delhi, INDIA. isolation, poverty, academic stress are some of the factors responsible for increasing stress, the list though is not exhaustive.(Lever, 2004; Hawkins \& Booth,2005; Marum, Clench-Aas, Nes \& Raanaas, 2014; Lelkes, 2013; Akhtar \& Alam,2015).

Although, it may not be easy to fully understand or eradicate the factors causing unhappiness, research indicates that simple interventions have the potential to increase human well-being. While ideally the benefits of well-being interventions should reach all humanity, a widespread reach is nonetheless possible if we can ensure happiness interventions across entire school population. The schools become the obvious choice, one, because of the easy availability of a large population in schools, secondly, it is the also the ability of children to benefit from the social environment and emerge as active learners with greater potential to adapt to new situations and assimilate newer learnings (Vygotsky, 1978 cited in National Research Council, 2000).

Among various attempts to defining happiness, assessing its need, weighing the benefits, delineating the determinants as well as to providing measures to increase human happiness, it is the field of positive psychology which proves to be most conclusive in terms of offering an understanding about happiness and suggesting measures to increase positive affect, decrease negative affect, as well as attain a sense of life satisfaction and well-being. Positive psychology interventions boast the potential to bring positive change in human behaviour and experiences. Although, it should be taken into consideration that many of the strategies and understandings developed in the field of positive psychology are themselves interdisciplinary in nature and there are overlaps between the positive psychology intervention strategies and teachings from the spiritual leaders and ancient texts, including philosophical readings. The empirical evidence shared in this text, however, is more psychological in nature.

The aim of this systematic review is to examine the empirical evidence of the influence of various strengths and virtues as delineated in the VIA classification of strengths and other positive psychology interventions on well-being. For the purpose of the review, comprehensive screening was performed using databases- ERIC, JSTOR, ProQuest Central, Google scholar and libraries (books, dissertations) to locate pertinent literature published in English language over the last 20 years. The search was completed till April 16, 2019. For the review paper, "Recent trends in Happiness Research", search term combinations included "Positive affect terms' (e.g. Happiness, Well-being, positive emotions, joy), population terms (e.g.

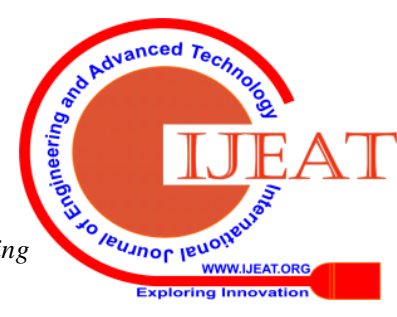




\section{Recent Trends in Happiness Research}

school, students, university students, teachers) Positive Psychology intervention (well-being intervention, interventions) terms and knowledge terms (Perception, construct, concept, beliefs, attitudes).

All relevant titles and abstracts were read by the authors to assess eligibility for inclusion and the non-conforming articles were removed.

\section{HAPPINESS AND EDUCATION}

When we talk about happiness and more specifically about enriching happiness of others, the first question that is put forth is what exactly it means to be happy. Happiness studies across disciplines have propounded various models and descriptions of happiness. The below mentioned descriptions is an attempt to lend clarity to the construct of happiness.

Michalos (2007) gave a description of happy person as, "A happy person is likely to have low levels of fear, hostility, tension, anxiety, guilt and anger; high degrees of energy, vitality and activity; a high level of self-esteem and an emotionally stable personality; a strong social orientation; healthy, satisfying, warm love and social relationships; an active lifestyle with meaningful work; and to be relatively optimistic, worry-free, present-oriented and well-directed." Seligman, (2013) traded the term Happiness in favour of well-being, as he believed the former to be narrow in its scope. He defined well-being as a construct encompassing five measures of positive emotion, engagement, meaning, positive relationships and accomplishment (PERMA) to increase human flourishing. In the context of student happiness, Hughes, S.F. (2016) described happiness as a feeling associated with positive affect, experienced through embracing positive habits of mind and heart, nurturance of the spiritual dimension and establishment of positive relationships.

Michalos (2007) further underlines the influence of education on happiness. He purports that how the terms 'happiness', 'influence' and 'education' are defined and operationalized, defines the relationship between education and happiness. He claims, it is the robust definition that promises an enormous effect on human well-being. He advocates an education not limited to formal education, but one that extends to include both non-formal and informal education. An education not just driven by marks but includes learning and pedagogies which are outside the realm of narrow academic form of education. Further, in the robust definition of happiness, it is the Aristotelian view that gains prominence, "living well and doing well'. An individual can be said to be happy when he enjoys the goods of the mind, the body as well as the external goods of wealth, material resources, relationships, peace and security. The influence herein includes both direct and indirect associations between the different kinds of education as well as the varied features of a happy life.

While both internal and external features are expounded as essential for creating experiences of happiness, both transient and stable aspects are also cited. By adopting a rounded meaning of the constructs of education and well-being, schools can play a vital role in improving student well-being. The schools have a great potential to bring about a positive change by creating an enabling and empowering environment for the children to explore their world in a holistic and stress-free manner. No curriculum would have ever stressed on the knowledge imparted by the books, but the reductionist view of education, cramming texts to get good grades, has been all pervading. Mere mugging up of text books can seldom help us achieve the true meaning of education. The focus needs to shift towards developing the skills and knowledge that caters to various domains of our being- the physical, motor, social, emotional, spiritual as well as cognitive. The education cannot limit itself to the classrooms and there is a grave need for schools to revise their processes and pedagogies to fulfil their responsibility of nurturing the children for a better and flourishing present and future.

\section{POSITIVE PSYCHOLOGY INTERVENTIONS}

Education's massive role in human development is well recognised, however it is the narrow economic orientation that has taken precedence and has led to a limited view of education as securing future economic prospects. Schools are becoming more and more mechanical and stress is on loading volumes of information with little attention being paid to nurturing the true nature of human beings. However, there is little doubt of the limitations of this single-minded approach. Education has a larger aim of holistic development of individual, of which securing sound financial prospects is only a part. Education can play a pivotal role in unloading the brain of the stress generated due to faulty orientation of education and can positively work towards the realisation of the highest goal of human happiness, which is also positively corelated to the positive learning outcomes.

James (1978) identified in humans, energies that have the potential for not only increasing the economic outcomes but also of leading fulfilling lives and he purports that education should play a role in nourishing these energies (cited in Pawelski, 2018). These energies are similar to what in positive psychology jargon are being referred to as character strengths and virtues as suggested by Pawelski (2018). Values in Action (VIA) classification of character strengths and virtues by Christopher Peterson and Martin Seligman (2004), is a psychological assessment measure which offers the possibility to identify and foster individual strengths to enhance human flourishing. The VIA inventory framework consists of 24 positive traits condensed further into character strengths or virtues - cognitive strengths (virtue of wisdom), emotional strengths (courage), social \& community strengths (humanity \& justice), protective strengths (temperance), and spiritual strengths (transcendence). The twenty-four-character traits are a medium through which the core virtues are attained. For example, attainment of the virtue of wisdom through strengths of creativity, curiosity, love of learning, open-mindedness, and perspective (Peterson, \& Seligman, 2004). The six virtues outlined are 
found to be consistent with the core characteristics valued across philosophical and ancient religious ideologies, and deemed contributory to a good life (Peterson, \& Seligman,
2004).

The character strengths and virtues proposed by Peterson, C., \& Seligman, M. E. P. (2004) are tabulated below:

Table 1. VIA Character Strengths and Virtues

\begin{tabular}{|c|c|c|c|c|c|}
\hline WISDOM & COURAGE & HUMANITY & JUSTICE & $\begin{array}{l}\text { TEMPERANC } \\
\text { E }\end{array}$ & TRANSCENDENCE \\
\hline CREATIVITY & BRAVERY & KINDNESS & FAIRNESS & FORGIVENESS & $\begin{array}{l}\text { APPRECIATION OF } \\
\text { BEAUTY }\end{array}$ \\
\hline $\begin{array}{l}\text { Thinking of new ways } \\
\text { of doing things }\end{array}$ & $\begin{array}{l}\text { Does not shrink } \\
\text { from } \\
\text { challenge, } \\
\text { difficult, } \\
\end{array}$ & $\begin{array}{lr}\text { Kind } & \text { and } \\
\text { generous } & \text { to } \\
\text { others. } & \end{array}$ & $\begin{array}{l}\text { Treat all } \\
\text { people fairly. }\end{array}$ & $\begin{array}{l}\text { Forgiving those } \\
\text { who have done } \\
\text { wrong to self. }\end{array}$ & $\begin{array}{l}\text { Notices and } \\
\text { appreciates beauty } \\
\text { and excellence in all } \\
\text { domains of life. }\end{array}$ \\
\hline CURIOSITY & HONESTY & LOVE & LEADERSHIP & HUMILITY & GRATITUDE \\
\hline $\begin{array}{l}\text { Likes exploration and } \\
\text { discovery. }\end{array}$ & $\begin{array}{l}\text { Lives life in a } \\
\text { genuine and } \\
\text { authentic way. }\end{array}$ & \begin{tabular}{ll}
\multicolumn{1}{l}{ Values } & close \\
relations & with \\
others. &
\end{tabular} & $\begin{array}{l}\text { Excel at } \\
\text { encouraging a } \\
\text { group to get } \\
\text { things done. }\end{array}$ & $\begin{array}{l}\text { Does not seek } \\
\text { attention. The } \\
\text { persons modesty } \\
\text { is recognized and } \\
\text { valued by others. }\end{array}$ & $\begin{array}{l}\text { Aware of good things } \\
\text { that happen and } \\
\text { doesn't take them for } \\
\text { granted. }\end{array}$ \\
\hline JUDGMENT & PERSEVERANCE & $\begin{array}{l}\text { SOCIAL } \\
\text { INTELLIGENC } \\
\text { E }\end{array}$ & TEAMWORK & PRUDENCE & HOPE \\
\hline $\begin{array}{l}\text { Thinks things through } \\
\text { and examines them } \\
\text { from all sides. }\end{array}$ & $\begin{array}{l}\text { Works hard to } \\
\text { finish what has } \\
\text { been started. }\end{array}$ & $\begin{array}{l}\text { Knows how to fit } \\
\text { in to different } \\
\text { social situations. }\end{array}$ & $\begin{array}{lll}\begin{array}{l}\text { Excels as } \\
\text { member }\end{array} & \text { of } & \text { a } \\
\text { group. } & & \\
\end{array}$ & $\begin{array}{l}\text { Is a careful } \\
\text { person. }\end{array}$ & $\begin{array}{l}\text { Expects the best in the } \\
\text { future, and works to } \\
\text { achieve it. }\end{array}$ \\
\hline LOVE-OF-LEARNING & ZEST & & & $\begin{array}{l}\text { SELF } \\
\text { REGULATION }\end{array}$ & HUMOR \\
\hline $\begin{array}{l}\text { Is passionate about } \\
\text { mastering new skills, } \\
\text { topics, and bodies of } \\
\text { knowledge. }\end{array}$ & $\begin{array}{lr}\begin{array}{l}\text { Approaches } \\
\text { everything }\end{array} \text { with } \\
\begin{array}{l}\text { excitement } \\
\text { energy. }\end{array} & \text { and } \\
\end{array}$ & & & $\begin{array}{l}\text { A disciplined } \\
\text { person. }\end{array}$ & $\begin{array}{lr}\text { Bringing smiles } & \text { to } \\
\text { other people } & \text { is } \\
\text { important for self. } & \end{array}$ \\
\hline PERSPECTIVE & & & & & SPIRITUALITY \\
\hline $\begin{array}{l}\text { Considered wise by } \\
\text { people. }\end{array}$ & & & & & $\begin{array}{l}\text { Actions are shaped by } \\
\text { beliefs and are a } \\
\text { source of comfort. }\end{array}$ \\
\hline
\end{tabular}

Adapted from: http://www.viacharacter.org/www/Character-Strengths

Character strength education is aimed at enriching students' moral virtues such as respect, compassion, responsibility, self-control and loyalty (Park,2004). These strengths are purported to be possessed by all human in varying degree and the nourishment of these positive traits offers the potential to provide buffer against life challenges and offer joyful experiences of living and being (Peterson \& Seligman, 2004). Positive psychology as "a science of positive subjective experience, positive individual traits, and positive institutions" advocates a range of exercises such as, 'The Gratitude Visit', 'What-Went-Well Exercise' that can lead to improved well-being among people (Seligman \& Csikszentmihalyi, 2000; Seligman \& Csikszentmihalyi, 2014; Seligman, 2013).

Many researchers have focused on identifying these strengths and devising interventions and study its impact on human well-being. Weber, Wagner and Ruch (2016), in their work with school children, revealed strongest positive correlations between school-related positive affect and the character strengths of zest, love of learning, perseverance and social intelligence. Optimism and perseverance, were shown to enhance student wellbeing (Oppenheimer, Fialkov, Ecker \& Portnoy, 2014). Further, gratitude based interventions led to a significant increase in life satisfaction and positive affect and a decrease in negative affect in at risk children (Harlan,2016). Negative correlation was found for traits such as teamwork, hope, self-regulation, and love and school-related negative affect, buffering the impact negative affect may have on functioning and success at school (Weber, M.; Wagner, L. and Ruch, W.,2016).

Schein (2014), in his study arrived at a preliminary definition of spiritual development as a system that enhances self- awareness among children and nurtures development of prosocial personality traits of caring, kindness, empathy, and reverence. He purported that such nurturance is brought about with love and attachment, by modelling and supporting children's unique

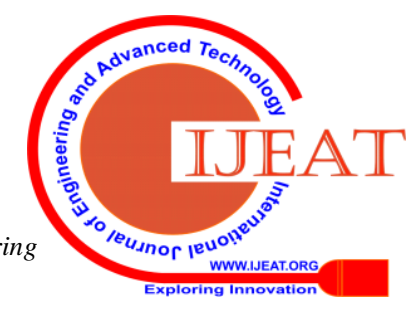




\section{Recent Trends in Happiness Research}

nature, character and temperament. Further, practicing mindfulness increases spiritual intelligence, which, in turn, improves the mental health of students (Nemati et al, 2017). The students who are high on mindfulness and dimensions of spiritual intelligence exhibit better understanding and acceptance of the realities of life and better coping abilities thus promoting mental health (Nemati et al, 2017). High consistency level has been found in levels of personal spirituality and positive psychology traits of forgiveness, gratitude, optimism, grit, and meaning with individuals high in personal spirituality and positive psychology traits exhibiting a negative association with depressive symptoms (Barton \& Miller, 2015).

Tian, Chen \& Huebner (2014) found significant bidirectional longitudinal relationships between autonomy, relatedness, and competence needs satisfaction and school satisfaction, with competence being the most significant factor predicting school related well-being. To determine predictive role of forgiveness on subjective happiness, Batık, Bingöl, Kodaz, \& Hoşoğlu (2017) revealed a positive but a weak relation between students' level of forgiveness and subjective happiness. The study also revealed that students enrolled in the Faculty of Theology reported higher on measures of forgiveness. The dimension of religiosity finds further support in increasing subject well-being in participants in a study led by Krok (2014). Religiousness led to an increase in the thoughts and feelings of meaning in life which acts as a mediator between religiosity and subjective well-being.

Support for positive psychology school-based intervention was also found in the works of Shoshani and Steinmetz (2013) wherein students post intervention showed significant decreases in general distress, anxiety and depression symptoms and a strengthening of self-esteem, self-efficacy and optimism, with reduced interpersonal sensitivity symptoms. Positive effects of School-wide Positive Behaviour Interventions and Supports (SWPBIS) on attendance were observed, which are in turn, is closely related to drop-out rates at the high school level (Freeman, Simonsen, McCoach, Sugai, Lombardi, \& Horner (2015).

Additionally, association between personality dispositions and experienced well-being have been found in general extraversion and most of its facets such as cheerfulness, assertiveness, activity level and excitement-seeking have been found to have significant and indirect effects on subjective happiness via general positivity. (Lauriola and Iani, 2016).

A lot of research has also been focussed on delineating the importance of human connections for furthering the goal of happiness. Lending relevance to the social domain, O'Rourke \& Cooper (2010) in their study with primary-aged students in Year 4 and 6 indicated that children's happiness was strongly predicted by a sense of friendship, belonging and optimism. Moreover, engaging in cognate activities such as reading and shopping, with parents are significantly associated with child happiness. (Anand \& Roope, 2016). In its implication for the education system, Chen (2011), proposed education promotes happiness by enabling individuals to have extensive social networks and greater engagements with the wider world, a life condition positively associated with happiness. In his survey on four East Asian countries Japan, Taiwan and South Korea, non-monetary factors such as interpersonal network and degree of cosmopolitanism were found to take precedence over monetary factors in accounting for a significant proportion of the association between education and happiness.

The studies have implications for the education system and emphasises a revival of the educational processes and pedagogies. The need is to supplement the formal academic oriented education with a more holistic approach, benefitting from the empirical data to foster student well-being.

\section{MEDIATING ROLE OF TEACHERS}

Teachers have a momentous role in the realisation of students' potential. Teachers beliefs and attitudes, their conceptions about well-being and their own well-being measures are important indicators of their quality of interactions with students. It is beyond doubt that teachers who are themselves stressed can do little to instil the virtues essential for a good life in their students. The mere imposition of intervention programs aimed at student enhancement and well-being on teachers without due consideration to their own personal wellbeing features is likely to result in futile efforts. It is therefore imperative that any interventions planned for children must take teachers into consideration.

This view is supported in a study conducted to determine the predictive role of happiness and a teachers' level of satisfaction with life, on their classroom management profiles. The study revealed that happiness and satisfaction with life were predictors of different classroom management styles. While a positive relationship between happiness and satisfaction with life, predicted an appreciative classroom management profile, negative relationship led to an indifferent classroom management profile (Ihtiyaroglu,2018). Further, Teachers psychological and job related well-being were found to be associated with their career orientation which in turn related to their attitudes on child centredness and support towards developmentally appropriate teaching practices (Hyun-Joo, Kyong-Ah, Bridget, Melissa \& Yun-Jung, 2019).

Building teachers abilities to enhance better understanding of students and planning appropriate interventions has been stressed. Focus needs to be paid to teachers developmental and well-being needs through providing support in planning meaningful and engaging activities for students (Hughes, 2016). For teachers to be able to create happy individuals the schools have to work towards building teachers capabilities to identify, implement, adapt and sustain practices essential to develop positive habits in the students. Providing support to teachers can improve teacher competencies and attitudes and enable better understanding of their students along with improved pedagogical planning and learning outcomes. (Truscott et al.,2012). 


\section{CONCLUSION}

The expanding literature on happiness studies and empirical evidence on happiness states of individuals and societies points at the dire need to focus on the well-being aspects of individuals. Efforts have been initiated across the globe to mitigate the factors causing human stress and misery as well as enhancing conditions that lead to prosperity and well-being. The adoption of Sustainable Development Goals by various world states is an indication that well-beings' needs are well recognised and accepted. With the aim to reduce poverty, bring about economic and social parity and enhancing living conditions to promote attainment of peace and prosperity, SDGs are aligned to improving human well-being.

People have a natural propensity to be happy, they plan their lives around happiness, however, they are often misguided or misinformed about the path that leads them to it. Encapsulating the learnings of various disciplines including teachings from various religious and ancient texts on pathways to a good life, the current work in the field of Positive Psychology has offered many plausible interventions to increase human well-being. Progress has been made in recognizing the inherent potencies and strengthening them for enabling individuals to lead meaningful and fulfilling lives. Plethora of activities have been propounded based on empirical evidence that holds potential for better outcomes. Further, research focussed on improving well-being measures of school and university students have been promising. Evidence indicates reduction in levels of distress, anxiety, depressive symptoms and school drop-out rates as well as increased self-esteem, self-efficacy, optimism and improved academic performance. Although the behavioural and relationship patterns of family members have a determinant role in defining the characteristics of an individual, the role of Positive psychology offers potential for strengthening human flourishing. The techniques outlined by Positive psychology are contemporary, cost effective and easy to interpret and implement.

Considering well-being as the ultimate goal of life, the education system can provide a significant platform for furthering the goal of human flourishing through implementation of evidence-based well-being interventions across schools and Universities. Further, as teachers play a crucial role in their students' development, teachers' developmental and well-being needs also require attention. Teachers' have the potential for not only making the intervention programmes successful but also sustainable. They can be a driving force in designing and implementing well-being programmes that are appropriate for their students and empower them to navigate through life stressors and emerge as successful and happy individuals.

\section{DIRECTIONS FOR FUTURE RESEARCH}

There is a plenty of research in the positive psychology domain. However, the long-term impact of these interventions needs to be studied in detail. Further, as most of these interventions involve school and university students, it will be interesting to understand the role of teachers in enhancing student well-being through these interventions. Research on teachers' beliefs and notions about well-being and teachers own well-being needs need exploration to further study its impact on their interactions with students. School environment and the role of teachers seem to be important factors in ensuring student happiness and well-being and thus requires further attention.

\section{REFERENCES}

1. Akhtar, Z., \& Alam, M. (2015). Stress and suicidal ideation among school students. Journal of the Indian Academy of Applied Psychology, Vol. 41(2),pp. 236-241. Retrieved from:

2. https://search-proquest.com.library.britishcouncil.org.in:4443/docview/1 779874572 ? accountid $=145163$

3. Anand, P. and Roope, L. (2016). The development and happiness of very young children. Social Choice and Welfare, 47(4) pp. 825-851. https://doi.org/10.1007/s00355-016-0993-9

4. Barton, Y., \& Miller, L. (2015). Spirituality and Positive Psychology Go Hand in Hand: An Investigation of Multiple Empirically Derived Profiles and Related Protective Benefits. Journal of Religion and Health, 54(3) 829-843. Retrieved from http://www.jstor.org.library.britishcouncil.org.in:2048/stable/24485453

5. Buchanan TW, Bibas D, Adolphs R (2010) Associations between Feeling and Judging the Emotions of Happiness and Fear: Findings from a Large-Scale Field Experiment. PLoS ONE 5(5): e10640. https://doi.org/10.1371/journal.pone.0010640

6. Chen,W. (2011). How Education Enhances Happiness: Comparison of Mediating Factors in Four East Asian Countries. Soc Indic Res (2012) 106:117-131. doi: 10.1007/s11205-011-9798-5

7. Deborah M. and MacLeod, S. (2015). Determinants of Happiness in Undergraduate University Students [Abstract]. College Student Journal, vol.49, pp.452-460. Abstract retrieved from: https://eric.ed.gov/?q=HAPPINESS+AND+EDUCATION\&pg=2\&id= EJ1095449

8. Freeman, J., Simonsen, B., McCoach, D., Sugai, G., Lombardi, A., \& Horner, R. (2015). An Analysis of the Relationship Between Implementation of School-wide Positive Behavior Interventions and Supports and High School Dropout Rates. The High School Journal, 98(4), 290-315. Retrieved from http://www.jstor.org.library.britishcouncil.org.in:2048/stable/44077793

9. Harlan, P. (2016). Effects of a positive psychological intervention on happiness in an at-risk students (Order No. 10240045). Available from ProQuest Central. (1844973724). Retrieved from https://search-proquest-com.library.britishcouncil.org.in:4443/docview/ 1844973724 ? accountid $=145163$

10. Hughes,S.F.(2016). Landmarks of Happiness: Conversations With Teachers About Happiness as an Aim of Education Paper presented at the 2016 annual meeting of the American Educational Research Association. Retrieved 09/04/2019, from the AERA Online Paper Repository. http://www.aera.net/Publications/Online-Paper-Repository

11. Hyun-Joo,J.,Kyong-Ah,K.,Bridget,W.,Melissa

M.B \&Yun-Jung,C.(2019).Relations of Early Childhood Education Teachers' Depressive Symptoms, Job-Related Stress, and Professional Motivation to Beliefs about Children and Teaching Practices.Early Education and Development. Vol.30(1),pp.131-144. Retrieved from:https://eric.ed.gov/?q=teachers+beliefs+on+student+well+being\&p $\mathrm{g}=5$ \&id=EJ1199349

12. Ihtiyaroglu, N. (2018). Analyzing the Relationship between Happiness, Teachers' Level of Satisfaction with Life and Classroom Management Profiles. Universal Journal of Educational Research. Vol 6(10),pp. 2227-2237. doi: 10.13189/ujer.2018.061021

13. Krok,D.(2014).The Religious Meaning System and Subjective Well-Being: The Mediational Perspective of Meaning in Life. Archive for the Psychology of Religion, Vol. 36, No. 2 ,pp. 253-273. Retrieved from: https://www.jstor.org/stable/23919072?seq=1\&cid=pdf-reference\#page _scan_tab_contents

14. Lelkes, O. (2013). Minimising Misery: A New Strategy for Public Policies Instead of Maximising Happiness? Social Indicators Research 114(1), 121-137. Retrieved from http://www.jstor.org.library.britishcouncil.org.in:2048/stable/24719529

15. Marco Lauriola,M. and Iani,L.(2016). Personality, Positivity and Happiness: A Mediation Analysis Using a Bifactor Model. Journal of Happiness Studies Vol. 18, pp.

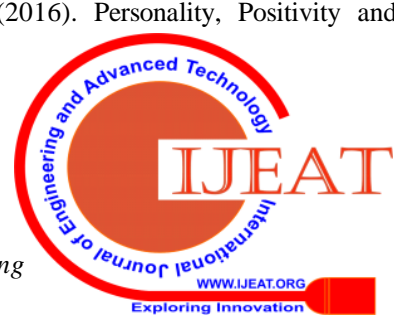




\section{Recent Trends in Happiness Research}

1659-1682. doi: 10.1007/s10902-016-9792-3

16. Marum, G., Clench-Aas, J., Nes, R., \& Raanaas, R. (2014). The relationship between negative life events, psychological distress and life satisfaction: A population-based study. Quality of Life Research, 23(2), 601-611. Retrieved from http://www.jstor.org.library.britishcouncil.org.in:2048/stable/24726561

17. Hawkins, D., \& Booth, A. (2005). Unhappily Ever after: Effects of Long-Term, Low-Quality Marriages on Well-Being. Social Forces, 84(1), 451-471. Retrieved from http://www.jstor.org.library.britishcouncil.org.in:2048/stable/3598312

18. Layous, K., Katherine Nelson, S. \& Lyubomirsky, S. J Happiness Stud (2013) 14: https://doi.org/10.1007/s10902-012-9346-2

19. Lever, J. (2004). Poverty and Subjective Well-Being in Mexico. Social Indicators Research, 68(1), 1-33. Retrieved from http://www.jstor.org.library.britishcouncil.org.in:2048/stable/27522102

20. Michalos, A.C. (2007). Education, Happiness and Wellbeing. Soc Indic Res ,Vol. 87:pp.347-366. doi: 10.1007/s11205-007-9144-0 National Research Council. 2000. How People Learn: Brain, Mind, Experience, and School: Expanded Edition. Washington, DC: The National Academies Press. https://doi.org/10.17226/9853.

21. Nemati,E., Habibi,M., Vargahan,F.A., Mohamadloo,S.S, Ghanbari,S. (2017). The role of mindfulness and spiritual intelligence in students mental health. Journal of Research \& Health. Vol. 7, pp: 594- 602. doi: 10.18869/acadpub.jrh.7.1.594

22. Oppenheimer, M. F., Fialkov, C., Ecker, B., \& Portnoy, S. (2014). TEACHING TO STRENGTHS character education for urban middle school students. Journal of Character Education, 10(2), 91-105. Retrievedfromhttps://search-proquest-com.library.britishcouncil.org.in:4 443/docview/1699516382? accountid=145163

23. O'Rourke, J. \& Cooper,M. (2010). Lucky to be happy: A study of happiness in Australian primary students Australian Journal of Educational \& Developmental Psychology. Vol 10, pp. 94-107. Retrieved from: https://files.eric.ed.gov/fulltext/EJ895559.pdf

24. Park, N. (2004). Character Strengths and Positive Youth Development. The Annals of the American Academy of Political and Social Science, 591, 40-54. Retrieved from http://www.jstor.org.library.britishcouncil.org.in:2048/stable/4127634

25. Peterson, C., \& Seligman, M. E. P. (2004). Character strengths and virtues: A handbook and classification. New York: Oxford University Press and Washington, DC: American Psychological Association.

26. Roorda, D.,Koomen, H., Spilt, J. \& Oort, F.J. (2011). The Influence of Affective Teacher-Student Relationships on Students' School Engagement and Achievement: A Meta-Analytic Approach. Review of Educational Research. Vol.81,pp. 493-529. Retrieved from: https://www.researchgate.net/publication/232920107 The Influence of Affective Teacher-Student Relationships on Students' School Engagement and Achievement: A Meta-Analytic Approach _

27. Schein,D. (2014). Nature's Role in Children's Spiritual Development. Children, Youth and Environments, Vol. 24, No. 2, Greening Early Childhood Education, pp. 78-101. Retrieved from: https://www.jstor.org/stable/10.7721/chilyoutenvi.24.2.0078

28. Seligman, M. E. P., \& Csikszentmihalyi, M. (2000). Positive psychology: An introduction. American Psychologist, 55(1), 5-14. http://dx.doi.org/10.1037/0003-066X.55.1.5

29. Seligman, M.P.(2013). Flourish: A visionary new understanding of happiness and well-being. New York.ATRIA.

30. Seligman M.E.P., Csikszentmihalyi M. (2014) Positive Psychology: An Introduction. In: Flow and the Foundations of Positive Psychology. Springer, Dordrecht

31. Shoshani,A. and Steinmetz,S.(2013). Positive Psychology at School: A School-Based Intervention to Promote Adolescents' Mental Health and Well-Being. Journal of Happiness Studies Vol.15(6), pp.1289-1311.doi: 10.1007/s10902-013-9476-1

32. The VIA Classification of Strengths(2019). Retrieved from http://www.viacharacter.org/www/Character-Strengths

33. Tian, L., Chen, H., \& Huebner, E. (2014). The Longitudinal Relationships Between Basic Psychological Needs Satisfaction at School and School-Related Subjective Well-Being in Adolescents. Social Indicators Research, 119(1), 353-372. Retrieved from http://www.jstor.org.library.britishcouncil.org.in:2048/stable/24721084

34. Tomyn, A., Weinberg, M., \& Cummins, R. (2015). Intervention Efficacy Among 'At Risk' Adolescents: A Test of Subjective Wellbeing Homeostasis Theory. Social Indicators Research, 120(3), 883-895. Retrieved from http://www.jstor.org.library.britishcouncil.org.in:2048/stable/24721178

35. Truscott, S. D., Kreskey, D., Bolling, M., Psimas, L., Graybill, E., Albritton, K., \& Schwartz, A. (2012). Creating consultee change: A theory-based approach to learning and behavioral change processes in school-based consultation. Consulting Psychology Journal: Practice and Research, 64(1), 63-82. http://dx.doi.org/10.1037/a0027997
36. UN General Assembly, Transforming our world : the 2030 Agenda for Sustainable Development (2015).Retrieved from: https://www.refworld.org/docid/57b6e3e44.html

37. Weber, M.; Wagner, L. and Ruch, W.(2016). Positive Feelings at School: On the Relationships Between Students' Character Strengths, School-Related Affect, and School Functioning. Journal of Happiness Studies, Vol. 17(1), pp. 341-355.doi :10.1007/s10902-014-9597-1 